\title{
Merete Wiberg \\ Dannelsesbegrebets rolle som regulativ ide i teoretisk pædagogik - Dannelsesbegrebet og den pædagogiske forskning
}

\begin{abstract}
In this paper, it will be argued that the concept of 'Bildung' has a twofold role in pedagogical research. On the one hand, it holds a position for conceptual analysis and discussions of how a pedagogical relation is established between an individual and the world. In this sense, it belongs to theoretical pedagogics. Humboldt concepts of receptivity and self-determination (Selbstätigkeit) and Klafki's theory of categorial pedagogy are central contributions to this discussion. On the other hand, the concept of Bildung has a role as a regulative idea due to the ideas and imaginations of various forms of humanity it contains. In this sense, it fulfills an ethical dimension since it is regulative for the pedagogical relationship between individual and world.
\end{abstract}

Nøgleord

Dannelse, teoretisk paedagogik, regulative ideer, humanitet, Humboldt, Klafki, Kant

\section{Introduktion}

Hvis man forestiller sig dannelsesbegrebets momenter fyldt i et bæger, så flyder dette dannelsesbæger over af forestillinger, ideer og betydninger, idet det rummer fortællinger om menneskers håb, muligheder, moralske fordringer og ikke mindst selvforståelse af at være et særligt betydningsfuldt væsen, der konstant er i en tilblivelsesproces gennem et verdensforhold. Dannelse er komponeret af fordringer, der er stillet af og til mennesker samt ideer og forestillinger om mulige verdensforhold. Disse ideer, forestillinger og fordringer kan umiddelbart virke overbevisende, men i sagens natur også umulige at svare på gyldigheden af. Spørgsmålet er, hvorvidt det kan godtgøres, at netop den type af ideer og forestillinger om menneskets verdensforhold samt de fordringer, som dannelsesbegrebet indeholder, har krav på at gøre sig gældende i pædagogisk forskning? Det nævnte spørgsmål skal ses i lyset af den bølge af evidenstænkning, som har haft stor indflydelse siden årtusindeskiftet. Hvilket med- eller modspil er dannelsestænkningen i en pædagogisk forskning, som især politisk forventes at levere synlige og dokumenterbare resultater?

På baggrund af ovenstående vil der i denne artikel blive argumenteret for, at, dannelsesbegrebet for det første indgår som teoretisk pædagogisk forskning med særligt henblik på

Merete Wiberg, Aarhus Universitet, Danmark

E-mail: wiberg@edu.au.dk

Studier i Pcedagogisk Filosofi | www.ojs.statsbiblioteket.dk/index.php/spf | ISSN nr. 22449140 
begrebsligt at undersøge pædagogiske verdens- og virkelighedsforhold og, at dannelsesbegrebet for det andet har en rolle som regulativ ide og på denne måde indtager en normativ og etisk funktion.

Artiklen har følgende opbygning: 1. Med henblik på at indkredse dannelsestænkningens rolle i den teoretiske pædagogik diskuteres det først, hvordan dannelsesbegrebet kan ses som tilhørende en anden tilgang end den forskningstilgang som evidenstænkningen tilhører. Dette afsnit fører videre til en afklaring af, hvilken forskningstilgang dannelsesbegrebet tilhører. 2. Inspireret af Husserls skelnen mellem en naturlig og en filosofisk åndholdning(Geisteshaltung) kategoriseres dannelsestænkningen som en tilgang, der karakteriseres af en filosofisk åndsholdning med særligt henblik på menneskets pædagogiske verdens- og virkelighedsforhold. 3 . I det følgende afsnit belyses dannelsesbegrebets tematisering af dette verdens- og virkelighedsforhold via dannelsesteoretikeren Wolfgang Klafki, og Humboldts begrebspar 'modtagelighed' og 'selvvirksomhed'. 4. Dernæst anvendes Kants tænkning om regulative ideer og fornuftens enhed til at godtgøre, hvordan dannelse kan forstås som regulativ ide for det aspekt af pædagogikken som vedrører etiske og normative forhold. 5. Afslutningsvis diskuteres dannelsesbegrebets tosidige rolle og dets betydning i pædagogisk forskning.

\section{Evidensbegrebet versus dannelse som et teoretisk pædagogisk begreb}

Med henblik på at afgrænse dannelsesbegrebets rolle i pædagogisk forskning vil det følgende afsnit tematisere, hvordan 'dannelse' og 'evidens' udpeger forskellige aspekter i pædagogisk forskning. Antagelsen i denne artikel er, at dannelsesbegrebets funktion og rolle i pædagogisk forskning er at tematisere et pædagogisk verdensforhold, der indeholder både erkendelsesteoretiske, ontologiske og etiske dimensioner. Heroverfor tematiserer evidensbegrebet i pædagogiske sammenhænge et ønske om et kausalt og sikkert forhold mellem metoder og ønsket virkning. Således vil man indenfor en evidenstænkning stræbe efter 'sikker viden' med henblik på opnåelse af 'sikker virkning' eller 'best practice', mens man indenfor en dannelsestænkning vil afvise, at pædagogik kan forstås i en sådan ramme i og med, at dannelsesbegrebet netop handler om forståelsen af, hvordan der i undervisning og læring kan etableres et åbnende og mulighedsskabende verdensforhold, der tillige indeholder en etisk dimension. Som sådan tematiserer evidens og dannelse forskellige tilgange til pædagogisk forskning.

Når der tales om evidensbasering inden for det pædagogiske område, så henvises der typisk til metoder, der tager udgangspunkt i manualtænkning og/eller henviser til kvantitative metastudier, som anvendes til at udpege 'best practice' metoder. Evidensbegrebet er imidlertid ifølge den norske filosof Tone Kvernbekk i disse sammenhænge sjældent genstand for undersøgelse, og det er derfor, at evidens i den uddannelsespolitiske debat ofte bliver synonymt med kvantitative metoder og Random Controlled Trial (RCT) metoder. Som Tone Kvernbekk gør opmærksom på, er der ikke i evidensbegrebet selv en særlig henvisning til RCT eller lignende metoder. Ifølge Kvernnbek, henviser evidens til den funk- 
tion at stå i en særlig relation til hypoteser med henblik på henholdsvis at bekræfte eller afkræfte disse. I en yderligere afdramatisering af evidensbegrebet, hvis man vel at mærke ser på det i et videnskabsteoretisk perspektiv, peger Kvernbekk på, at "The basic function of evidence is summed up in the word support. This is what evidence is: something that stands in a relation of support (confirmation, disconfirmation) to a theory or hypothesis" ${ }^{2}$

Kvernbekks nøgterne, minimalistiske og videnskabsteoretiske tilgang til evidensbegrebet er et vigtigt bidrag, fordi hun derved gør opmærksom på grænserne for evidensbasering. Endvidere peger hun på, at kausalitet og dermed forholdet imellem indsats og virkning er centralt i pædagogisk arbejde i og med, at professionelle i den pædagogiske praksis som oftest arbejder med henblik på at opnå en ønsket effekt, f.eks. at få elever til at lære at læse. Således er der ikke nogen nødvendighed i, at professionelle, der er inspireret af dannelsestænkningen skulle modsætte sig, at de metoder og tilgange de bruger i pædagogisk arbejde skal virke. Også dannelsestænkere ønsker, at børn skal lære at læse.

En kritik af evidenstænkningen kan derimod mere konstruktivt sættes ind i forhold til den måde, hvorpå evidensbegrebet bruges i uddannelsesforskningen og endvidere i forhold til, at dette risikerer at udelukke en særlig vigtig teoretisk tilgang i pædagogisk forskning, hvor grundlæggende ikke-empiriske kategorier udvikles med henblik på forståelse af fænomener som f.eks. mediering, åbenhed, modtagelighed, selvvirksomhed og normativitet. Med denne risiko in mente kan dannelsestænkningen alternativt betegnes som tilhørende teoretisk pædagogik, der opstiller modeller og mønstre for mulige verdensforhold, der eventuelt i andre sammenhænge kan efterprøves empirisk. Set i det lys tilhører dannelsestænkningen en tilgang, der potentielt set, via modeller, forestillinger og metaforer, kan åbne op for nye forståelser af pædagogiske verdensforhold. En særlig pointe med dannelsestænkningen er, at den altid vil rumme en normativ dimension i og med de fordringer begrebet stiller. Som begrebsligt rum for et eksperimentarium for disse fordringer og forestillinger, har dannelsesbegrebet en særlig normativ dimension, der kan indfanges ved at beskrive dannelsesbegrebet som regulativ ide.

\section{Dannelse mellem en naturlig og en filosofisk åndsholdning}

Som nævnt i indledningen skelner Husserl ${ }^{3}$ mellem en naturlig og en filosofisk åndsholdning Ifølge Husserl er der i den naturlige åndsholdning ingen erkendelseskritik. Mennesket lever, som det beskrives af Husserl, umiddelbart og eksistentielt ubekymret midt i verden. Det forholder sig til erfaringer, iagttagelser og erindringer og finder (logiske) forbindelser mellem disse. Den naturlige videnskab, som omfatter både materielle og ideelle genstande og såle-

1 Tone Kvernbekk, "The Concept of Evidence in Evidence-Based Practice", Educational Theory, 61(5) (2011), 516, Se endvidere Tone Kvernbekk, "Evidence-Based Practice: On the Function of Evidence in Practical Reasoning", Studier i Pædagogisk Filosofi 2 (2013):19-33. Accessed September 6, 2016, doi:10.7146/spf.v2i2.7348.

2 Tone Kvernbekk, Evidence-based Practice in Education. (London and New York: Routledge), 12

3 Edmund Husserl, Die Idee der Phänomenologie. Fünf Vorlesungen. Herausgegeben von Walter Biemel (Haag: Martinus Nijhoff, 1958 [1907]), 17. 
des omfatter naturvidenskab, åndsvidenskab og matematik, vokser ud af denne naturlige åndsholdning. Den naturlige videnskab er ikke fredfyldt, men beskrives som en kampplads, hvor der opstilles hypoteser, udvikles metoder, eksperimenteres og hvor viden skal gøre sig fortjent til anerkendelse, men Husserls pointe er, at foretagsomheden sker uden grundlæggende filosofisk refleksion.

Den filosofiske åndsholdning derimod viser sig, når der opstår en usikkerhed angående spørgsmålet om, hvordan erkendelse overhovedet er mulig::

"Erkendelsens mulighed bliver overalt til en gåde. Hvis vi indlever os i de naturlige videnskaber, så finder vi, såfremt de er eksakt udviklede, alt klart og forståeligt. Vi er sikre på at være i besiddelse af objektiv sandhed, begrundet gennem pålidelige metoder, der virkelig træffer objektiviteten. Så snart vi reflekterer, geråder vi imidlertid ud i vildfarelser og forvirringer.." ${ }^{14}$

Det er usikkerhed om erkendelsens mulighed, som er vejen til den filosofiske åndsholdning, der af Husserl betegnes som en helt anden dimension i forhold til den naturlige åndsholdning. For den filosofiske åndsholdning viser erkendelsesforholdet sig som gådefuldt (rätselhaft). ${ }^{5}$ Hvordan Husserl fortsætter med sin beskrivelse af den filosofiske videnskab falder uden for denne artikels rammer, da det i denne sammenhæng især er beskrivelsen af, hvordan det, der for den naturlige åndsholdning er et selvfølgeligt forhold til verden, for den filosofiske åndsholdning viser sig som gådefuldt, der er interessant i forhold til at forstå, hvordan dannelsestænkningen placerer sig i den pædagogiske forskning.

Husserls begreb om gåden, der opstår i tvivlen om erkendelsens mulighed, kan anvendes til at stille et spørgsmål om, hvorvidt der i dannelsestænkningen peges på en gåde eller en tvivl, som ikke viser sig i den evidenstænkning, der er fremherskende inden for det pædagogiske område? Hvis man antager, at der er indeholdt en gåde i form af en tvivl i dannelsestænkningen, som angår menneskets virkeligheds- og verdensforhold, så er spørgsmålet naturligvis, om det er muligt at formulere gåden? I lyset af en forståelse af dannelsestænkning som filosofisk åndsholdning er dannelsestænkningens rolle at åbne for og begrebsliggøre grundlæggende forståelser af, hvordan mennesker i pædagogiske sammenhænge indgår i verdensforhold samtidig med, at den gåde, som Husserl beskriver vedligeholdes. Hvorfor skal gåden vedligeholdes, kan man spørge? Et forsigtigt svar herpå er, at 'gåden' indeholder kilden til nødvendig refleksion over menneskets tilstedeværen i verden, og hvis denne refleksion ikke grundlæggende holdes i live, så kommer menneskene til at leve i en selvfølgelighedens verden, som måske er tryg, men som ikke rummer den tvivlens nådegave, som driver tænkningen.

4 Edmund Husserl, Fæenomenologiens idé (København: Hans Reitzels Forlag A/S, 1997 [1950, 1973]), 92. "Die Möglichkeit der Erkenntnis wird überall zum Rätsel. Leben wir uns in die natürlichen Wissenschaften ein, so finden wir, soweit sie exakt entwickelt sind, alles klar und verständlich. Wir sind sicher, im Besitz objektiver Wahrheit zu sein, begründet durch zuverlässige, die Objektivität wirklich treffende Methoden. Sowie wir aber reflektieren, geraten wir in Irrungen und Verwirrungen." Husserl, Die Idee der Phänomenologie, 21. 
Klafki beskriver, som det vil fremgå senere, det pædagogiske verdensforhold som en 'dobbelt åbning', idet han peger på at denne dobbelte åbning er pædagogikkens forudsætning. Metaforen om den dobbelte åbning rummer en refleksivitet vedrørende det pædagogiske verdensforhold, som er en forudsætning for at kunne rammesætte mere empiriske tilgange, idet disse nødvendigvis må bygge på en begrebsliggørelse af hvilke pædagogiske forhold, der skal undersøges, f.eks. ideen om, at der sker en mediering mellem individ og verden, at individet dannes i mødet med det, der er andet end det selv, og at begreberne modtagelighed og selvvirksomhed er centrale for at beskrive medieringen mellem individ og verden. Undersøgelser af empiriske forhold kræver udpegning af, hvor man skal rette blikket hen, hvilket oplagt kunne være medieringsprocessen, og dermed, hvad individer gør og forstår i mødet med 'det der er andet end dem selv, men som samtidig også udgør dem selv'. Det er ikke muligt direkte empirisk at iagttage fænomener som åbenhed, modtagelighed og selvvirksomhed, og dette forhold peger på at begrebsligt, filosofisk og teoretisk arbejde spiller en særlig rolle i pædagogisk forskning. En forudsætning for denne påstand er naturligvis, at nødvendigheden af denne type begreber medgives, hvilket er et forhold som kunne undersøges empirisk, og som relaterer sig til diskussionen om dannelsesbegrebet som regulativ ide.

Hvis tilgange, som udmøntes i begreber som 'best practice' eller'what works', kan ses som en umiddelbar og uproblematisk tilgang til verden, hvor der måles, bekræftes og afkræftes hypoteser, så kan dannelsestænkningen ses som en tilgang, der adresserer en gåde om et pædagogisk verdensforhold, der implicerer et normativt 'bør'. Når en person forstår, fordi noget i verden åbner sig for vedkommende, så viser der sig samtidig et spørgsmål om, hvad personen skal med forståelsen. Således blander 'modtagelighed' sig med 'selvvirksomhed', idet personen både skal være modtagelig og indsætte forståelsen i sin egen selvvirksomhed. Wilhelm von Humboldt anvender 'modtagelighed' og 'selvvirksomhed' på følgende måde: "Hvad mennesket altså nødvendigvis behøver er blot en genstand, som muliggør en vekselvirkning mellem menneskets modtagelighed og dets selvvirksomhed"6(Oversættelse MW). Dannelse udgøres således ifølge Humboldt af denne vekselvirkning mellem modtagelighed og selvvirksomhed, og det der er forudsætning herfor er mødet med 'en genstand', hvor denne genstand kan forstås som det, der er andet end individet selv, men som allerede er og bliver til en del af individet, herunder andre mennesker, historien, sproget, biologien og kulturen.

Spørgsmålet om, hvad der 'bør' opdrages og uddannes til, indeholder den gådefuldhed, at et 'bør' implicerer en fremtid, som ikke kendes. Men samtidigt implicerer et 'bør' et spørgsmål om, hvad mennesker kan håbe og ville i en fremtid. Denne problematik er ikke

6 "Was also der Mensch notwendig braucht, ist bloss ein Gegenstand, der die Wechselwirkung seiner Empfänglichkeit mit seiner Selbstthätigkeit möglich mache." Wilhelm von Humboldt, "Theorie der Bildung des Menschen". I Andreas Flitner und Klaus Giel (red.) Wilhelm von Humboldt. Schriften zur Antrophologie und Geschichte. Werke in Fünf Banden 1 (Darmstadt: Wissenschaftliche Buchgesellschaft, 1960[1793]), 237. 
til stede i begreber som 'best practice' og 'what works' i og med, at metaanalyser af, hvad der virker, af gode grunde kun omfatter det, der allerede er sket.

\section{Dannelse som en tematisering af et pædagogisk verdensforhold}

Dannelse angår, som det er fremgået, en grundlæggende mediering mellem henholdsvis en subjekt- og en objektorientering eller med andre ord et verdensforhold. Det interessante ved det særlige pædagogiske forhold, der tematiseres ved hjælp af dannelsesbegrebet er, at det indeholder en normativ dimension. I dette åbnende forhold sker der ifølge Humboldt en vekselvirkning mellem individets modtagelighed og dets selvvirksomhed. Strukturelt etableres en modtagelighed i form af en åbenhed, der medvirker til, at individet 'opdager', at der er noget andet end det selv. At individet 'opdager' noget forstås her ud fra Humboldts begreb om modtagelighed. Netop denne modtagelighed åbner for en normativ dimension i og med selve opmærksomheden for det andet tillægges værdi samtidig med, at dannelsesbegrebet tilbyder et indhold af regulative forestillinger og ideer, der henviser til, at verdensforholdet bør være reguleret af en overordnet ide om humanitet. At der henvises til humanitet fremgår af de ideer, der som det vil fremgå, indgår i beskrivelsen af det klassiske dannelsesbegreb, f.eks. myndighed, selvbestemmelse, selvvirksomhed og frihed. Således etablerer dannelsesbegrebet en pædagogisk relation, der er ide- og værdimæssigt reguleret. Denne regulerende indlejring i dannelsesbegrebet er interessant, og et centralt spørgsmål i den pædagogiske forskning må være, hvorvidt de ideer, der typisk har et værdimæssigt indhold, kan godtgøres.

Filosoffen Roland Reichenbach understreger i en diskussion af dannelsesbegrebet, at medieringsaspektet og the "idea of the subject" tilhører dannelsesbegrebets centrale kerne.? Som sådan understreger han, at dannelse i en humboldsk betydning peger på et verdensforhold. Yderligere argumenterer Reichenbach for, at dannelse må udgøre en regulativ ide for uddannelse. Denne argumentation sætter han overfor instrumentalistiske og pragmatiske tilgange til uddannelse. ${ }^{8}$

Det skal her indskydes, at dannelsesbegrebet kan forstås bredere end den kontinentale og overvejende germanske tilgang, som eksponeres her. En bredere tilgang bl.a. udfoldes i bogen Danningens Filosofihistorie, redigeret af Ingerid Straume, hvor dannelsens historie både beskrives historisk og i forhold til andre kulturer end den vestlige.' I Historisches Wörterbuch der Pädagogik udgivet af Dietrich Benner og Jürgen Oelkers er der derimod et klart fokus på den vestlige og især kontinentale tradition. ${ }^{10}$

7 Roland Reichenbach,"Humanistic Bildung: regulative idea or empty concept?," Asia Pacific Educational Review, 15(2014), 68, doi:10.1007/s12564-013-9298-1.

8 Ibid, 69.

9 Ingerid Straume, (red.). Danningens Filosofihistorie (Oslo: Gyldendal Akademisk 2013)

10 Dietrich Benner \& Jürgen Oelkers (red.), Historischen Wörterbuch der Pädagogik, (Weinham und Basel: Beltz Verlag, 2004). 
Klafki gør i sin redegørelse for dannelsesbegrebet opmærksom på, at der ikke er tale om én klassisk dannelsesteori, idet der i perioden 1770-1830, hvor dannelsesbegrebet blev en central pædagogisk kategori, var forskellige udlægninger af dette." Men ser man overordnet på de klassiske teorier om dannelse, er der følge Klafki en række gennemgående forestillinger og ideer, der indgår i dannelsesbegrebet.

Undersøger man det verdensforhold, som dannelsesbegrebet tematiserer, så bidrager Klafki med en strukturel bestemmelse af dette, idet han tilnærmer sig begrebet via henholdsvis en subjekt- og en objektorientering. Klafki opregner i forhold til den klassiske dannelse følgende: For det første er der de ideer og forestillinger, som især angår individet eller subjektet. Her er begreberne "selvbestemmelse, frihed, emancipation, autonomi, myndighed, fornuft, selvvirksomhed"12 centrale. Der er imidlertid en anden side af dannelsesbegrebet, hvor der ikke kun er fokus på individualitet og subjektivitet, men derimod på den objektive og sociale dimension. Her er følgende ideer og forestillinger ifølge Klafki centrale: "humanitet, menneskehed og menneskelighed, verden, objektivitet, almenhed."13 Klafki beskriver i overensstemmelse med denne opdeling medieringen mellem den subjektive og den objektive side således, at menneskets tilegnelsesproces kun kan opnås i mødet med det, der "ikke stammer fra subjektet selv."14

De to sider af dannelsesbegrebet, som Klafki sammenfatter, beskriver et dialektisk åbnende forhold mellem individ og verden og tematiserer således et pædagogisk verdensforhold reguleret af ideer, der udgår fra henholdsvis individet og verden. Klafkis pædagogik og didaktik er interessant i den forstand, at han pædagogisk og didaktisk forsøger at konkretisere, hvordan der skabes forbindelse mellem subjektet og verden med henblik på, at eleven eller den studerende lærer. ${ }^{15}$ Klafkis svar er, at dette at tilegne sig og lære kategorier er omdrejningspunkt for pædagogik og didaktik og Klafkis didaktik betegnes da også som kategorial dannelsesteori. Det er ifølge Klafki pædagogikkens, herunder didaktikkens opgave at arbejde med, at det lærende subjekt opbygger forskellige typer af kategorier, som på den ene side åbner verden for individet og på den anden side åbner individet for verden:

"Den opfattelse af det dynamiske forhold, som mennesket (i stadig udvikling) har til den historiske virkelighed, og som indeholdes i dannelsesbegrebet, udlægger jeg som tidligere i betydningen 'den kategoriale dannelses teori'. Dvs. som et formidlingsforhold, der altid

11 Wolfgang Klafki, Dannelsesteori og didaktik - nye studier (Århus: KLIM, 2011 [1985]), 27-28. I Historischen Wörterbuch der Pädagogik anføres der tilsvarende, at dannelsesbegrebet sætter sig igennem i det tyske sprogområde i midten af 1800-tallet. Samtidig beskriver redegørelse under opslaget 'Bildsamkeit/Bildung en fortælling om dannelse fra antikken og frem til det 20'århundrede. Denne spændvidde demonstrerer bredden i forståelsen af dannelsesbegrebets betydning (Benner \& Oelkers, Historischen Wörterbuch, 174). Roland Reichenbach fremfører, at dannelsesbegrebet ikke er et eksklusivt tysk begreb, og at det opstod senere i tysk end i fransk, engelsk og skotsk oplysningstænkning. Ifølge Reichenbach skete der i den tyske senoplysning et skift, hvor dannelse gik fra at være et politisk begreb til et begreb, der handlede om indre frihed. Se Reichenbach,"Humanistic Bildung”, 65-70.

12 Klafki, Dannelsesteori og didaktik, 32.

13 Ibid, 33.

14 Ibid, 34.

15 Ibid, 120. 
holdes åbent fremad, mellem 'subjekt' og 'objekt' altså en aktiv tilegnelsesproces, i hvilken den historiske virkelighed 'åbner sig' for det sig dannende menneske, bliver tilgængelig, forståelig, mulig at kritisere, foranderlig, og i hvilken subjektet samtidig åbner sig for den historiske virkelighed. [...] I lyset af det konkretes, enkeltes uendelige omfang er en sådan 'gensidig åbning' af subjekt og virkelighed dog kun mulig, hvis det lykkes at føre dette omfang af konkreter tilbage til grundlæggende former, strukturer, typer, forhold, kort sagt: Hvis det lykkes at reducere det til en struktur af kategorier, samt hvis det lykkes at muliggøre aktiv tilegnelse/ udvikling under dannelsesprocessen med pædagogisk støtte."16

Man kan her sammenligne med Humboldts beskrivelse af dannelse som en formidling mellem et individ og noget ydre, der som tidligere nævnt kan muliggøre en vekselvirkning mellem individets modtagelighed og dets selvvirksomhed: ${ }^{17}$

Også i Hegels filosofi er formidlings- eller medieringsdimensionen tydelig og viser sig i Åndens fænomenologi som det vedgående spil imellem en bevidsthed, der i forskellige skikkelser forsøger at forstå sin relation til sin genstand, og derigennem realiserer den absolutte ånd. Gadamer beskriver Hegels dannelsesbegreb således, at det især handler om at 'hæve sig op til det almene' og videre. at det er udannet, hvis man 'overgiver sig til partikulariteten.18 Som det fremgår, udpeger Klafki netop begrebet almenhed, som den objektorienterede side af dannelsesbegrebet, og læser man hans tænkning i et regulativt perspektiv, så er almenbegrebet ikke blot neutralt, men henviser til en værdimæssig regulering af individet. Også i den hegelske filosofi er der en regulering i individets vekselvirkning med sin genstand. Hegel beskriver bl.a. dannelsesprocessen på følgende måde:

"For individets magt består i dets tilpasning til substansen, dvs. dets evne til at yderliggøre sit eget selv og på den måde sætte sig selv som objektivt værende substans. Individets dannelse, og dets egen virkelighed, er dermed også virkeliggørelsen af substansen."19

Vægtningen er som det fremgår her på det almene og i mindre grad på individet. En fokusering på individet findes i højere grad $\mathrm{i}$ Kants tænkning, hvor autonomi er et centralt begreb. Der er imidlertid også fokus på det enkelte menneskes forståelse af det almene hos Kant, men via en tænkning som har sit analytiske udgangspunkt i individet. Dette ses bl.a. i Kants moralfilosofi, hvor moralloven har sit sæde i det enkelte menneskes (universelle) fornuft. ${ }^{20}$ Overordnet kan man om teorier om dannelse sige, at der er variationer i forhold til netop vægtningen mellem subjekt- og objektorientering, der kan ses som forskydninger i virkeligheds- og verdensforholdet samt i den normative regulering af dette. Medieringsbegrebet

\footnotetext{
Ibid., 120-121.

Von Humboldt, "Theorie der Bildung, 237.

8 Hans-Georg Gadamer, Sandhed og Metode. (Århus: Systime academic 2004 [1986]), 17.

19 Georg William Friedrich Hegel, Åndens fænomenologi (København: Gyldendals Bogklubber, 2007 [1807]), 341. På tysk lyder citatet således: "Denn die Macht des Individuums besteht darin, dass es sich ihr gemäss macht, d.h. dass es sich seines Selbst entäusen, also sich as die gegenständliche seiende Substanz setzt. Seine Bildung und seine Wirklichkeit ist daher die Verwirklichung der Substanz selbst." (Georg William Friedrich Hegel, Phänomenologie des Geistes (Frankfurt am Main: Suhrkamp Verlag, 1973 [1807], 365.

20 Immanuel Kant, Grundlegung zur Metaphysik der Sitten. (Hamburg: Felix Meiner Verlag 1963 [1785]).
} 
er interessant i denne sammenhæng, idet det er det analytiske begreb til at forstå, hvordan formidlingen/bevægelsen/det dobbelte greb sker.

Klafkis teori om kategorial dannelse kan beskrives som en kobling til og udvidelse af Humboldts teori i og med indsætningen af kategoribegrebet, der får den funktion, at det i en pædagogisk sammenhæng bredt konkretiserer, hvordan mennesker henholdsvis griber og gribes af verden ved hjælp af kategorier. Verdensforholdet nuanceres derved i og med, at verden konkretiseres ved hjælp af kategorier. Man kan her sammenligne til Hegels vedvarende begrebsnuancering i Åndens Fænomenologi, hvor bevidsthedens tiltagende og fremadskridende forståelse af virkeligheden gives fylde gennem begrebernes udvikling, der sker i netop en vekselvirkning mellem et subjektivt og et objektivt niveau.

Flytter man Hegels grundlæggende tanke om at begrebsudvikling fører til en nuanceret virkelighedsforståelse til Klafkis tænkning og dermed en pædagogisk sammenhæng, vil der være tale om f.eks. begreber, former, mønstre, tal, symboler, tabeller, oversigter og lignende. Pædagogik handler i denne forståelse om, at de lærende tilegner sig og udvikler kategorier med henblik på at få greb om verden.

Hvis ovenstående ide om kategorial dannelse skulle forstås i lyset af 'en naturlig indstilling' som f.eks. en 'best practice'-tilgang, så ville det sikkert være muligt operationalisere dette at tilegne sig kategorier og efterfølgende at måle succeskriterier, men spørgsmålet er, om en sådan operationalisering ville sige noget som helst om, hvad det vil sige at være et lærende menneske i en verden? Den gensidige åbning, som Klafki beskriver, er umulig at beskrive med andet end filosofiske begreber, om end man måske ville kunne måle biologiske ændringer i kroppen i forhold til den modtagelighed, som et menneske har i en given situation. Men 'åbningen', dette at være åben for verden samtidig med erfaringen af en verden, der åbner sig, kan hævdes at være et pædagogisk grundvilkår. Samtidig er 'åbningen' udtryk for et ønske, og dermed et udsagn om noget, der er ønskværdigt og det vil således være fejlslagent, hvis 'åbningen' ikke også anskues fra et etisk perspektiv. Dette ses f.eks. i Hegels dannelsestænkning, hvor mennesket som nævnt blev anset som udannet, hvis det ikke kunne se ud over partikulariteten. I Kants moralfilosofi beskrives en gensidig åbning mellem det enkelte individ og et fælleskab i og med Kants pligtbegreb, der udmøntes i det kategoriske imperativ, og som byder mennesket at handle således, at det kan ville, at den regel, det handler efter, kan blive til en almengyldig lov: "handl kun ifølge den maksime ved hvilken du samtidig kan ville, at den bliver en almengyldig lov.". ${ }^{11}$

Klafki bestemmer dannelse som sammenhængen mellem 3 grundlæggende evner: selvbestemmelsesevne, medbestemmelsesevne og solidaritetsevne. ${ }^{22}$ Disse 3 evner henviser til værdierne selvbestemmelse, medbestemmelse og solidaritet og indeholder idealer for menneskers vilkår og mulige praksis. I særlig grad henviser solidaritetsbegrebet til en

21 Immanuel Kant, Grundlaggelse af sæedernes metafysik (København: Hans Reitzels Forlag 2014 [1785]), 78. "..handle nur nach derjeningen Maxime, durch die du zugleich wollen kannst, dass sie ein allgemeines Gesetz werde" Kant, Grundlegung, 42 [421].

22 Klafki, Dannelsesteori og didaktik, 69. 
åbning, hvor det selvbestemmende individ griber ud efter det, der er andet end det selv med henblik på at overskride sig selv. Disse forestillinger og ideer kan ses som regulative ideer for menneskelige samværsformer.

Almenpædagogikken, således som den udformes af den tyske pædagogiske tænker Dietrich Benner, er et eksempel på teoretisk pædagogik, idet bestræbelsen her er at udforme teoretiske refleksioner over grundlæggende pædagogiske begreber, som f.eks. dannelse med henblik på at yde en refleksionskraft til den pædagogiske praksis og empiriske forskning. ${ }^{23}$ Benner er i sin tilgang til dannelsesbegrebet inspireret af Rousseaus tænkning, og udvikler bl.a. på denne baggrund en ikke-affirmativ dannelsestænkning, hvor pointen er, at mennesket vedvarende skal udfordres på, hvad det tager for givet. Grundlæggende tager Benner, som de øvrige nævnte dannelsestænkere i denne artikel, udgangspunkt i et humboldsk dannelsesbegreb, hvor dannelse forstås som et verdensforhold, der viser sig som en vekselvirkning mellem menneske og verden, idet mennesket bestemmer sig selv $i$ udvekslingen med verden..$^{24}$. Benner lægger som det fremgår særlig vægt på den kritiske, ikke-affirmative dimension i denne vekselvirkning. Benners tænkning er et eksempel på udvikling af pædagogiske begreber, der netop tematiserer kritisk refleksivitet og negativitet i vekselvirkningen mellem individ og verden.

Sammenligner man med Klafkis dannelsestænkning tematiserer Klafki i højere grad den normative dimension, bl.a. med sin senere udvikling af epokale nøglebegreber for pædagogisk praksis.

Ser man på ovenstående skitsering af begreber, der i den tyske dannelsestradition kan udpeges som centrale for konstitueringen af et pædagogisk verdens- og virkelighedsforhold, så kan man spørge, hvad disse begreber rent faktisk bidrager med i pædagogisk forskning, og om de kan godtgøres som gyldige? Måske skal spørgsmålet vendes rundt, idet det kan overvejes, hvorvidt disse begreber kan undværes? Er det muligt at tænke pædagogik med andre grundlæggende kategorier end denne vekselvirkning mellem et selvvirksomt subjekt, der modtageligt møder noget andet det selv med henblik på, at der i dette møde sker en formidling/mediering gennem en eller anden instans, som f.eks. de kategorier, som Klafki fremfører eller med Benners tematisering af negativitet? Svaret herpå må være, at det naturligvis er muligt, men at spørgsmålet om hvordan pædagogiske begreber udvikles grunder i, hvordan vi forstår, herunder hvordan vi ønsker at forstå mennesket, idet synet på mennesket er en grundlæggende præmis for den pædagogiske forskning. Inspireret af den humanistiske psykolog Rogers' diskussion med behavioristen Skinner, vil jeg afslutte dette afsnit med en pointe Rogers fremførte i bogen On Becoming a Person i 1961. ${ }^{25}$

Rogers pointe var, at han måtte medgive, at Skinner havde ret $\mathrm{i}$, at adfærdsregulering virkede, men at det $\mathrm{i}$ forskning i sidste ende handler om grundlæggende valg vedrørende vores syn på mennesket. Den pædagogiske forskning undgår ikke at foretage grundlæg-

23 Dietrich Benner, Allgemeine Pädagogik (Weinham og Basel: Beltz Juventa, 2015), 335.

24 Ibid., 162.

25 Carl Rogers, On Becoming a Person (London: Constable 2004 [1961]), 400. 
gende valg vedrørende forståelsen af hvad det vil sige at være menneske. Dannelsesbegrebet bidrager til denne diskussion med modeller, metaforer, ideer og forestillinger om, hvad det vil sige at være menneske i et verdensforhold.

\section{Dannelse og det fornuftige menneske}

Dannelsestænkningen har i en tysk oplysningstradition ideen om det fornuftige menneske som omdrejningspunkt. Mange filosoffer har igennem historien gennemført denne fortælling om det fornuftige menneske, som har en særlig værdighed pga. sin fornuft. Denne fortælling er oplysende i forhold til at forstå, hvorfor dannelsesbegrebets regulative ideer i høj grad tematiseres om humanitet.

At forstå menneskets menneskelighed som konstitueret af en fornuft er ikke nødvendigvis uproblematisk. Men indledende skal Kants argumentation for sammenhængen mellem fornuft og menneskets særlige værdighed skitseres. Kant argumenterer på følgende måde. For det første beder han os om at antage, at der findes noget, der har absolut værdi i sig selv. Hvis et sådan noget findes, siger Kant, så må det være det, der skaber mulighedsbetingelsen for et kategorisk imperativ ('Grund eines möglichen kategorischen Imperativs)'. ${ }^{26}$ Kant hævder derefter, at mennesket og ethvert andet fornuftigt væsen eksisterer som mål i sig selv. Samtidig legitimeres det kategoriske imperativ som et fornuftsindhold, fordi mennesket ifølge Kant er et objektivt mål, dvs. at det ikke kun er middel for noget andet. Det har værdi uanset virkning. Pointen med Kants argumentation er at få begrundet nødvendigheden af det kategoriske imperativ og at få vist, at det har en sådan karakter, at det må være placeret i menneskets fornuft:

\footnotetext{
"Skal der da gives et øverste praktisk princip og et med hensyn til den menneskelige vilje kategorisk imperativ, så må det være af en sådan art, at det udgør et for viljen objektivt princip, der kan tjene som almen praktisk lov, i og med det udledes af forestillingen om det, der for alle og enhver er et bindende mål, fordi det er et mål i sig selv. Og grundlaget for dette princip er da: den fornuftige natur eksisterer som mål i sig selv. Således fremstiller mennesket sig nødvendigvis sin egen tilværelse, og for så vidt er det altså et subjektivt princip for menneskelige handlinger. ${ }^{27}$
}

Umiddelbart kan det synes som om, at Kants påstand om menneskets absolutte værdi legitimerer det kategoriske imperativ. Mennesket som et væsen, der har værdi i sig selv, og som derfor har en særlig værdighed, er oplysningstænkningens antropocentriske fortælling om mennesket. Hvis man dertil lægger Kants opdragelsesprincipper, således som de

26 Kant, Grundlegung, 50 [428].

27 Immanuel Kant, (2014 [1785]), 88. På tysk lyder citatet:"Wenn es denn also ein oberstes praktisches Prinzip und in Ansehung des menschlichen Willens einen kategorischen Imperativ geben soll, so muss es ein solches sein, das aus der Vorstellung dessen, was notwendig für jedermann Zweck ist, weil es Zweck an sich selbst ist, ein objektives Prinzip des Willens ausmacht, mithin zum allgemeinen praktischen Gesetz dienen kann. Der Grund dieses Prinzips ist: die vernünftige Natur existiert als Zweck an sich selbst. So stellt sich notwendig der Mensch sein eigenes Dasein vor; sofern ist es also ein subjektives Prinzip menschlicher Handlungen." Kant, Grundlegung, 51 [428-429]. 
er gengivet i forelæsningerne Om predagogi $k^{28}$, så er det endelige mål med opdragelsen at gøre mennesket moralsk ved, at det lærer at bruge sin fornuft. Således handler opdragelse om aktivering af det menneskelige i mennesket, hvor det menneskelige er karakteriseret ved fornuften. Ser man på de af Klafki udpegede klassiske dannelsesbegreber - selubestemmelse, frihed, emancipation, autonomi, myndighed, fornuft, selvvirksomhed og humanitet, menneskehed og menneskelighed, verden, objektivitet, almenhed - så er de, hvis man ser dem inden for rammen af oplysningstænkningen og den tyske idealisme, beslægtede. Frihed og autonomi er beslægtet med fornuft, fordi det menneske, der følger sin fornuft, ifølge Kant er selvlovgivende og derfor autonomt og frit. Samtidig kan det med begreberne fornuft, autonomi og frihed beskrives som selvvirksomt og myndigt. Skal man pege på en central gåde i dannelsestænkningen, så er det gåden om, hvorfor menneskelighed skal konstitueres via ideen om fornuft og, hvorfor mennesket pga. denne sammenkobling har en ganske særlig værdighed. Forstår man dannelsesbegrebet refleksivt og teoretisk pædagogisk, så bliver det klart, at spørgsmålet ikke kan besvares entydigt, men at spørgsmålet om, hvad der konstituerer det menneskelige netop altid er til diskussion. Et eksempel på dette er udfordringen til dannelsesbegrebet i Jan Maschelein og Ricken Norbergs artikel "Do we (still) need a concept of Bildung". I artiklen udfordrer de dannelsestænkningens egen selvfølgelige forestilling om at have et særligt kritisk potentiale i forhold til vores forstålse af, hvad det vil sige at være menneske, herunder det at kunne forholde sig til andre mennesker:

"Even if at one moment in history it probably did play a critical role, Bildung has long since lost the possibility of functioning as a point of resistance and critical principle for analyzing the ways in which we conduct our lives and the ways in which our conduct is itself conducted, i.e. the ways we are governed and also govern ourselves." ${ }^{29}$

Udfordringen er her i høj grad til forestillingen om, at dannelsesbegrebet kan have en regulerende funktion i verdensforhold, herunder pædagogiske verdensforhold. I artiklen beskriver de, inspireret af Foucault, at dannelsesbegrebet historisk har været indvævet i magtforhold, der har ført til en særlig individualiseret ('government of individualisation') ${ }^{30}$ forståelse af mennesket. Som alternativ foreslår de, at dannelsesbegrebet opgives til fordel for andre måder at forstå 'being-together'. Dvs. at dannelsesbegrebet her smides ud, fordi det ifølge forfatterne er behæftet med en grundlæggende fejl, nemlig individorienteringen. Hvorvidt et nutidigt dannelsesbegreb skal forstås i overensstemmelse med oplysningstidens fornuftsbegreb står til diskussion. Udfaldet af en sådan diskussion står og falder med, hvorvidt oplysningsprojektet står til troende eller ej. Igennem filosofihistorien er det blevet udfordret flere gange, ikke mindst af Frankfurterskolen med blandt andet Horksheimer og Adornos centrale værk Oplysningens Dialektik ${ }^{31}$. Værket blev skrevet kort efter

28 Immanuel Kant, Om predagogik (Århus: Klim/Samlerens bogklub (2000[1803]).

29 Jan Maschelein \& Ricken Norberg, "Do we (still) need the concept of Bildung". I Educational Philosophy and Theory, 35, (2) 2003: 139.

30 Ibid., 139, 142.

31 Max Horkheimer \& Theodor Wisengrund Adorno, Dialektik der Aufklärung (Frankfurt am Main: Fischer Verlag 1985 [1947]) 
2.verdenskrig og krigens grusomhed var i sig selv et tegn på oplysningstankens forfald. Også den voksende kulturindustri var ifølge forfatterne et tydeligt tegn på forfaldet og nivelleringen af den menneskelige fornuft.

Ikke desto mindre kan der argumenteres for, at dannelsesbegrebet har en vigtig funktion med henblik på at være pladsholder for en tematisering af det pædagogiske verdensog virkelighedsforhold..

I det følgende afsnit skal der fokuseres på den rolle som dannelsesbegrebet, her med udgangspunkt i humboldske og klafkiske dannelsesbegreb, har som regulativ ide. Dvs. den normative og etiske funktion, som dannelsesbegrebet har med henblik på at opstille begrundede bør'er for pædagogikken.

\section{Dannelsesbegrebets etiske dimension: regulative ideer}

Hvis man anvender Kants begreb om regulative ideer, så kan man hævde, at dannelsesbegrebet kan udgøre en overordnet regulativ ide for opdragelse og uddannelse. Kants begreb om regulative ideer indskriver sig som bekendt $i$ hans argumentation for enhed $i$ fornuften med henblik på samvirket mellem forstand og fornuft. ${ }^{32}$ De regulative ideer er endvidere kendetegnet ved, at de ikke som forstandens kategorier forbinder sig med et erfaringsmæssigt grundlag, men derimod knytter sig til menneskets metafysiske spørgen ${ }^{33}$. Kants anerkendelse af disse ideers funktion i både menneskets erkendelse og i dets moralske liv ${ }^{34}$, hvor ideen om frihed får en central betydning som et nødvendigt postulat, er et vidnesbyrd om, at han ikke blot smider det ud med badevandet, som ikke empirisk kan godtgøres, men netop anerkender dets funktion. Ser man dannelsesbegrebet i lyset af Kants anerkendelse af menneskets påtrængende metafysiske spørgen, så giver det mening at forstå det som en regulativ ide for pædagogikken og den pædagogiske forskning.

I Kritikken af den rene fornuft advarer Kant mod at gå ud over erfaringens grænser, men samtidig erkender Kant, at mennesket i og med sin fornuft netop går ud over erfaringen, idet fornuften producerer transcendentale ideer. ${ }^{35}$ Kants teori om, at menneskets fornuft producerer en række særlige regulative ideer, er overbevisende også empirisk, fordi det kan konstateres at, mennesker faktisk producerer denne type af ideer. Kant ser ikke dogmatisk på disse ideer, men erkender at mennesket producerer dem med henblik på at opnå enhed i fornuften og erfaringen. Det interessante er endvidere, at et forsøg på at få disse ideer (sjælen, verden og fornuftens ideal) til at fremstå som realt eksisterende genstande i erfaringen gennem logiske slutninger vil føre til selvmodsigende konsekvenser, fordi man ikke tydeligt nok har skelnet mellem erfaringen og dens (aprioriske) forudsætninger..

32 Immanuel Kant, Kritik der reinen Vernunft, (Stuttgart: Reclam (1982[1787]), 673-695 [B670-B696].

33 "Woher hat denn die Natur unsere Vernunft mit der rastlosen Bestrebung heimgesucht, ihm als einer ihrer wichtigsten Angelegenheiten nachzuspüren?" Ibid., 27 [XIV-BVI].

34 Ibid., 36 [BXXVII-BXXIX].

35 Ibid., 673-695 [B670-B696]. 
Imidlertid har disse ideer en enhedsskabende funktion i den rene og spekulative fornuft, som Kant i sin afsøgning og kritik forsøger at forstå som et fuldstændigt system ${ }^{36}$.

At mennesket producerer disse ideer kan betegnes som gådefuldt, men samtidig er det disse ideer, der som følge af et fornuftkrav ifølge Kant får systemet til at 'gå op' og dermed medvirker til at opretholde en enhed i mangfoldigheden.

Hvorvidt Kants systemtænkning og tro på fornuftens enhed giver mening i en tid, hvor postmodernistisk tænkning har sat sine spor, skal ikke diskuteres i det følgende. Derimod er forslaget, at dannelsesbegrebet med dets indhold af forestillinger og ideer forstås som regulativ ide ud fra følgende rationale:

Hvis pædagogisk forskning kun bedrives som empirisk forskning, og hvor kravet er empirisk dokumentation, så mangler der et sted i pædagogikken, hvor det er muligt at stille spørgsmål til, hvad mennesker tør håbe på, og herunder mulige svar på spørgsmål om, hvad de bør gøre. Kant stiller disse berømte spørgsmål i Kritik der reinen Vernunft i afsnittet 'Von dem höchsten Guts, als einem Bestimmungsgrunde des letzten Zwecks der reinen Vernuft': "1. Was kann ich wissen? 2 Was soll ich tun? 3. Was darf ich hoffen? ${ }^{37}$ Som det fremgår så spørger Kant ikke kun om, hvad vi kan vide, men netop om, hvad vi bør gøre, og hvad vi tør håbe på. Disse spørgsmål er relevante i pædagogikken, som ikke blot har det aktuelle eller fortiden som genstand, men også fremtiden og de håb, der kan være for denne. Der er således brug for at kunne forholde sig til noget idealt. De regulative ideer kommer ind her. Hvorvidt det er muligt at bevise friheden eller Guds eksistens er et andet spørgsmål, og en væsentlig pointe hos Kant er, at han netop ikke beviser, men i sin praktiske filosofi postulerer disse ideer. Det centrale er Kants påstand om at disse begreber opstår i og med den menneskelige fornuft, hvor det i tråd med den tidligere diskussion om fornuftsbegrebet skal understreges, at også begrebet 'fornuft' er en betegnelse på en instans, som ikke empirisk direkte kan eftervises, men hvis funktion måske indirekte kan udledes.

Disse begreber indgår i en løbende samtale om, hvordan mennesker skal forstå sig selv og deres menneskelighed. Mennesker producerer begreber, der kan vejlede dem i at få en sammenhængende forståelse af, hvad de bør gøre og hvad de bør håbe på.

Man kan naturligvis diskutere, hvorvidt disse ideer har deres udspring alene i den menneskelige fornuft, således som Kant hævder, eller om de opstår på baggrund af menneskers omgang med den empiriske verden. F.eks. vil en pragmatisk tænker som John Dewey hævde, at ideer opstår i mennesket interaktion og møde med den empiriske verden. Endvidere, at ideer har den rolle, at være retningsgivede og operative i forhold til menneskets handlen i verden ${ }^{38}$. Således er Kant og Dewey til dels enige på et operativt niveau, men ikke på et ontologisk og erkendelsesteoretisk, hvor der er væsentlige forskelle mellem de to filosoffer. Den centrale pointe i denne sammenhæng er, at mennesker på den ene eller

36 Ibid., $726-727$ [B735-736]. Se endvidere, 839 [B860-B861].

37 Ibid., 815 [B832-B833].

38 John Dewey, The Quest for Certainty. John Dewey, The Later Works, Vol. 4. J. A. Boydston (red.) (Carbondale and Edwardsville: Southern Illinois University Press 1990 [1929]). 
anden måde producerer ideer, og at dannelsesbegrebet opsamler en særlig type af ideer, der angår menneskets verdensforhold, og at der i dette verdensforhold er indlejret en etisk dimension. Dannelsesbegrebet tilbyder regulative ideer til det pædagogiske verdensforhold med henblik på menneskets tilblivelse.

Kants argumentation for eksistensen af regulative ideer bruges her i relation til en forståelse af dannelsesbegrebets rolle som regulativ ide. Dannelsesbegrebet udgør med sit indhold af forestillinger og ideer om et gensidigt åbnende verdensforhold en central regulativ ide for pædagogikken. Samtidig er det klart, at dannelsesbegrebets udfoldede indhold af normative regulative ideer må kunne diskuteres og transformeres, men at der samtidig er en grundlæggende præmis, der beskrives i det verdensforhold, som udlægges. Nemlig at der er tale om en gensidig åbenhed med henblik på at det enkelte individ må forstå sig selv ud fra noget andet end sig selv, det være sig interpersonelt, historisk, kulturelt eller materielt. Derudover har dannelsesbegrebet som pædagogisk forskningstilgang sin berettigelse i sin stadige teoretiske udkasten af dette verdensforhold, som udmærker sig ved at kombinere erkendelsesteoretiske, ontologiske og etiske dimensioner.

\section{Afslutning: Dannelsesbegrebet som teoretisk pædagogisk begreb og som regulativ ide}

Hvilken rolle spiller dannelsesbegrebet i pædagogisk forskning? Nærværende artikel har forsøgt at svare på dette spørgsmål ved at fokusere på to centrale bidrag, som dannelsesbegrebet yder. På den ene side tematiserer dannelsesbegrebet et pædagogisk verdensforhold, som i denne sammenhæng især har været belyst via Humboldt og Klafki. På den anden side har dannelsesbegrebet en rolle som regulativ ide, idet dets indhold af forestillinger og ideer er regulerende for det verdensforhold, som mennesker i en dannelsesproces indgår i med henblik på læring, dannelse og udvikling. Overordnet er buddet på dannelsesbegrebets rolle i pædagogisk forskning, at det er pladsholder for en vedvarende diskussion af et pædagogisk verdensforhold, samt for en diskussion af de forestillinger og ideer, som dannelsesbegrebet er fyldt med. Dannelsesbegrebet tilhører i overensstemmelse med ovenstående udlægning den del af pædagogisk forskning, som kan betegnes teoretisk pædagogik.

Teoretisk pædagogik kan forstås som et begrebsligt eksperimentarium, hvor begreber, modeller, forestillinger og ideer udkastes. I relation til dannelsesbegrebet er det som nævnt det pædagogiske verdensforhold og de regulative ideer, som er genstand for afklaring og undersøgelse. Den vigtige pointe er, at begrebsligt arbejde altid vil være en side af pædagogisk forskning uanset om begreberne kan siges at være afledt af empiri eller om de produceres af den menneskelige fornuft.

Hvorvidt og hvordan man kan gøre dette arbejde til genstand for empirisk afprøvningvil jeg i denne sammenhæng lade ligge til udforskning i en anden sammenhæng. 